\title{
LAS ESTELAS TARTÉSICAS: ¿LOSAS SEPULCRALES, MARCADORES ÉTNICOS O REPRESENTACIÓN DE DIVINIDADES GUERRERAS?
}

\author{
TARTESSIAN STELAE: FUNERARY SLABS, ETHNIC MARKERS \\ OR REPRESENTATIONS OF WARRIOR DEITIES?
}

\author{
ANTONIO TEJERA GASPAR* \\ JESÚS FERNÁNDEZ RODRÍGUEZ* \\ MARCOS RODRÍGUEZ PESTANA*
}

\begin{abstract}
Resumen: Este trabajo pretende revisar un aspecto arqueológico singular y controvertido del Bronce Final del SW peninsular: las estelas decoradas o estelas de guerreros. Se analizan distintas hipótesis vertidas sobre estos monumentos, ofreciendo nuevas interpretaciones sobre su contexto arqueológico e iconografía, proponiendo una lectura en clave mítica y religiosa de las imágenes antropomorfas y los símbolos que las acompañan.
\end{abstract}

Palabras claves: Bronce Final, estelas de guerreros, interpretación mítica y religiosa.

Con este trabajo no pretendemos dar respuesta a los muchos problemas que aún siguen planteados sobre la interpretación cultural y simbólica de las estelas tartésicas, del sur y oeste peninsular. Por ello, sólo nos limitaremos a hacer una serie de propuestas sobre aspecto arqueológico tan singular de la cultura tartésica, que ha de ser explicado necesariamente en el marco de las manifestaciones de esta civilización protohistórica.

Cualquier hipótesis que se plantee sobre estos monumentos entraña una gran dificultad, debido a la falta de datos bien elaborados acerca del contexto económico, social y político de los tartesios. Y de todos estos

\footnotetext{
* Universidad de La Laguna (Tenerife)
}

\begin{abstract}
This work claim to revise one archaeological and singular aspect of the Final Bronze in the South West of the Iberian Peninsula: the decorated steles or steles of warriors. We analyse different hypotheses about these monuments, offering new interpretations about its archaeological contexts and also about its iconography, making one lecture in mythical and religious key about the human images and its symbols.

Key words: Final Bronze Age, steles of warriors, mythical and religious interpretation.
\end{abstract}

problemas, el más importante es, sin duda, el relativo a su pensamiento mítico y religioso, cuestión de las peor conocidas de esta cultura, pero que resulta primordial, sin embargo, para realizar cualquier análisis de estas características, como tendremos ocasión de ver.

Con relación a lo dicho, es necesario tener en cuenta algunas cuestiones, de las que destacaremos, sobre todo, la relativa a la escasez de fuentes escritas de la civilización tartesia, al menos si se compara con las de otros ámbitos geoculturales, como el mundo griego o romano. El contraste de las fuentes escritas y los testimonios arqueológicos, es un método ya suficientemente ensayado en estas y otras culturas que ha resultado de gran ayuda para corroborar, en su caso, los 
datos de ambos repertorios, aunque para el tema que estudiamos no es posible avanzar mucho en este sentido, por lo que hemos de conformarnos, por el momento, con las evidencias arqueológicas, de las que no siempre resulta fácil trascender en aspectos, ciertamente complejos, como el de su cosmogonía, cuya reconstrucción se hace difícil sin el concurso de los testimonios literarios con los que entender debidamente estos hechos.

Las reflexiones que aquí presentamos no van acompañadas ciertamente de un gran cuerpo teórico (aunque nuestras propuestas están fundamentadas en los presupuestos de la arqueología antropológica y en las herramientas que ofrece el método comparativo ${ }^{1}$ ), ni quieren tampoco aportar soluciones mágicas para resolver los problemas aludidos. Nuestra pretensión es mucho más sencilla. Se trata de exponer una serie de ideas con la intención única de profundizar en algunos de estos aspectos para tratar de saber un poco más de lo mucho que sobre este tema ya se ha hecho y se conoce, y asimismo con el deseo exclusivo de contribuir a una discusión que complemente las diferentes hipótesis manejadas hasta el presente. La propuesta que haremos sobre la interpretación de lo figurado en dichos monumentos sólo se refiere a las conocidas "estelas decoradas", o "estelas de guerreros", dejando fuera las denominadas "estelas diademadas" y las alentejanas, por considerar que unas y otras se enmarcan en un ambiente cultural que si no distinto, no nos parece -al menos por ahora-, que respondan a un mismo contexto social y religioso, e igual sucede con las estelas en las que figuran elementos propios de ambas iconografías que seguramente obligará a replantear algunas de las cuestiones que aquí se expresan, pero que por el momento preferimos no entrar en esa discusión.

Previo al planteamiento de nuestra hipótesis de trabajo, nos ha parecido oportuno revisar algunas de las propuestas más relevantes que hasta el momento se han hecho sobre las estelas. Con ello sólo pretendemos poner de manifiesto la existencia en todas de un cierto hilo conductor, un patrón común, que las une. Con todo, parece necesario advertir al lector que estamos ante un fenómeno de cierta amplitud cronológica y espacial, con lo que las estelas se nos presentan como elementos polifuncionales, posiblemente imaginadas y utilizadas según las diversas necesidades de cada grupo social y territorial, verosímil reflejo de la diversidad y complejidad de los valores simbólicos que puede llegar a otorgarse a lo natural y a lo sagrado en cada momento y sociedad. Lo expuesto podría quedar constatado a partir

1. Puede verse una justificación científica del método comparativo en Diez de Velasco (1995: 31-32, con bibliografía). de los grabados añadidos a posteriori en algunas estelas (bien analizados por Celestino, 2001²), o a través de las distintas reutilizaciones a las que son sometidos estos monumentos: desde el aprovechamiento de una estatua-menhir en el caso de la estela de "Talavera de La Reina", pasando por el uso que se les otorga en el período orientalizante en algunos lugares de culto ("Cancho Roano", "Montemolín", etc.) y funerarios ("Toya" y "Setefilla"), hasta su ulterior empleo en época romana (estelas de "Torrejón El Rubio IV", "Iberhernando" o "Chillón”). Y que no sabemos si responden a un fenómeno de continuidad o a diversidad de funciones.

\section{LAS ESTELAS COMO LOSAS FUNERARIAS}

De todas las propuestas, seguramente la que más eco ha alcanzado ha sido la de considerar a estos monumentos como losas funerarias o indicadores de enterramientos, por lo que a la figura humana se le ha relacionado, de un modo u otro, con la representación de la muerte de un guerrero al que le acompaña una rica panoplia de armas y otros objetos de prestigio. Y algunas, como las del tipo I, se definieron por M. Almagro (1966:199) como laudas sepulcrales o tapas horizontales de fosas para inhumación, que organizadas con otras lajas puestas verticalmente, formaban las cajas o cistas donde se colocaba al muerto. Esta hipótesis ha sido, sin duda, la que más se ha divulgado y la que ha contado con más seguidores. Todo ello se debió a que el primer hallazgo de una de estas estelas, la de "Solana de Cabañas" (Logrosán, Cáceres), se encontró -al parecer- asociada a restos de cenizas, haciendo pensar que podría ser éste su destino, por ser la función que a dichos monumentos se les suele atribuir en otras culturas, en donde comúnmente se hallan hincadas en el suelo en posición vertical, o también para tenderlas sobre la sepultura de un cadáver inhumado (Almagro 1966:27). Esta estela, que fue dada a conocer al mundo científico por el naturalista y erudito Mario Roso de Luna, en 1898, junto a otra aparecida ese mismo año en el arroyo de Bonaval, cerca de Almendralejo (Badajoz), contribuyó a que se relacionasen con losas funerarias, creyendo que con este hallazgo se confirmaba el destino que se le había atribuido primeramente a la encontrada en Cáceres.

Los fundamentos de esta hipótesis, aunque débiles como veremos, fueron defendidos por el prof. Almagro, cuando se refería a las circunstancias del hallazgo de "Solana de Cabañas", diciendo que "se había conservado

2. A título de ejemplo, véase el caso de la estela de Torrejón El Rubio IV (Celestino 2001: 333). 
si no "in situ" exactamente sí cerca de la tumba para la que fue labrada. La losa estaba sobre una sepultura, pero, a su vez, fue cubierta con piedras sueltas, amontonadas sobre ella, formando un majano". Se habla de "ligeras cenizas como de esqueleto humano", según la expresión usada por Roso de Luna, mientras que Almagro creía, sin embargo, que este autor debió escribir: "ligeros restos de esqueleto humano". Estas circunstancias y las del hallazgo de la "Granja de Céspedes" (Badajoz), así como otras de procedencia portuguesa, contribuyeron a que las estelas se asociasen con este carácter funerario, creyendo que "unas veces cubrían las sepulturas y en otras ocasiones se colocarían hincadas al lado de las tumbas de inhumación de personajes de especial distinción social, a los que dedicaron estos curiosos monumentos arqueológicos" (Almagro 1966: 9).

A partir de estos pocos hallazgos relacionados con enterramientos, a los que a las estelas se les vinculó con lastras funerarias para cubrirlos, se hicieron, a nuestro juicio, excesivas generalizaciones sin que se contara aún con datos suficientes para sostener dicha hipótesis. Otro documento manejado por M. Almagro para enriquecer su hipótesis, se relaciona con la de la "Granja de Céspedes" (Badajoz), que "fue hallada con toda seguridad cubriendo una sepultura de inhumación. Pudo haber estado en pie y luego haber caído sobre el cadáver, sepultado allí, aplastándolo a lo largo del tiempo, pues en el momento de ser hallado y recogido este monumento fueron encontrados debajo de él los restos, ya muy descompuestos, de un cadáver" (A1magro 1966:105), a los que consideró que "no tenían valor alguno antropológico, pues eran escasos trozos, todos muy rotos y descompuestos, pero se veía pertenecían a unos huesos largos y algunos trozos de cráneo, todo ello, como decimos, muy descompuesto y machacado" (Almagro 1966:107). De lo anterior no es fácil obtener una conclusión muy precisa sobre el valor de estas evidencias de las que no queda claro, ni la forma en la que se encontraron, ni tan siquiera podemos concluir que se tratara ciertamente de huesos humanos. En todo caso, el citado investigador consideró de mucho interés esta información porque le permitía vincular tales restos con una sepultura de inhumación, de manera que venía "a confirmar las confusas referencias sobre la losa grabada de Solana de Cabañas, que también fue hallada sobre una sepultura en la que se hallaron restos del cadáver inhumado" (Almagro 1966: 107). Estas seguridades, sin embargo, se contradicen en parte con las aparentes confusiones con las que él mismo presenta este descubrimiento en su importante catálogo sobre las estelas, al que nos venimos refiriendo.
La endeblez de los argumentos manejados sobre la supuesta asociación de las estelas como cubiertas de tumbas, se puede comprobar, además de en lo dicho, en la descripción que conocemos de lo publicado con ocasión del hallazgo de la estela de "Figueira", procedente de Lagos, en el Algarve portugués. Sus divulgadores la dieron a conocer como un monumento que cubría una tumba, aunque en esta ocasión M. Almagro dice que cerca "se hallaron unas lajas de piedras dispersas y no es seguro que esta estela apareció cubriendo unos restos humanos hallados dentro de una cista que estaría señalada por una estela" (Almagro 1966: 72).

Los hallazgos posteriores en los que estos hechos no pudieron ser contrastados con suficiente nitidez, han contribuido a que esta primera hipótesis, si no desechada del todo, al menos haya sido objeto de diferentes matizaciones, a pesar de que todavía -aunque ciertamente sólo de forma esporádica- se les pretende asociar con esta función. Es cierto, sin embargo, que existen algunos pocos casos aislados en los que se podrían relacionar con esta finalidad, aunque un análisis detallado y una lectura detenida del contexto en el que aparecieron no permite verificarla de manera rigurosa.

En una futura revisión de estos monumentos, quizá habría que reflexionar de nuevo sobre el hallazgo de tales cenizas y, en su caso, de restos óseos en el entorno de estas estelas, con el fin de determinar si tales evidencias pertenecieron realmente a huesos humanos, ya que no cabría desdeñar que formaran parte de algún ritual, que es de suponer alguno se hiciera en el entorno de las estelas del yacimiento de "Hernán Pérez" (Cáceres), en el caso de que el conjunto de las cuatro allí localizadas, así como las lajas de los alrededores, seguramente asociadas con ellas, hubieran cumplido alguna función en ese sentido.

\section{LAS ESTELAS COMO MARCADORES ÉTNICOS}

Otra de las hipótesis sobre la interpretación de las estelas, ha sido la de considerarlas marcadores de territorios, que servirían como indicadores de rutas de ganado, o como hitos visuales de control y reclamación de recursos, especialmente ganaderos (Ruiz-Gálvez y Galán 1991; Galán 1993; Ruiz-Gálvez 1998: 265-269). Para entender esta propuesta parece necesario hacer algunas reflexiones sobre los argumentos manejados. La primera cuestión nos lleva a preguntarnos si las gentes de la cuenca Media y Baja del Guadalquivir tendrían necesidad de realizar grandes traslados con el ganado desde esos lugares, ya que para ello es necesario conocer los recursos potenciales del territorio, de manera 
que en el supuesto de tratarse realmente de zonas con escasas posibilidades para alimentar los animales, entonces sí parece que se verían forzados a la búsqueda de otras áreas de pasto situadas a tanta distancia, pero para ello es imprescindible saber si los lugares adonde llevaban estos animales eran mejores que los de su procedencia, porque de lo contrario no resulta fácil entender la necesidad de hacer tamaños desplazamientos. Nos parece importante tratar de conocer estos aspectos, porque en caso contrario estaríamos trasladando situaciones propias del presente hacia el pasado, a sabiendas de que en ningún caso los acontecimientos históricos fueron siempre los mismos, como tampoco en otras épocas las condiciones del medio. Utilizar criterios del presente para explicar hechos del pasado siempre plantea problemas, porque no sólo eran distintas aquéllas, sino también las bases de su economía, ya que los terrenos ocupados hoy por explotaciones agrícolas no lo estarían necesariamente en otras épocas, de manera que el espacio potencialmente utilizable para el pasto destinado a grandes rebaños, sería de seguro distinto a este otro donde el sistema de propiedad de la tierra fue, sin duda, bien diferente y, desde luego irreconocible hoy si se observara desde el pasado.

Esta hipótesis, que sin duda resulta muy sugerente, debe ser explicada, en todo caso, a partir del conocimiento de la estructura sociopolítica de Tarteso sobre la que algunos investigadores, que han tratado estas cuestiones, se han referido al alto nivel de centralización política que se debió de alcanzar -cuando menos en la etapa del contacto con fenicios y griegos-, como asimismo una estructura social muy jerarquizada, que se fundamentaría en una economía compleja y productora de excedentes, a la que se le asociaría una aristocracia guerrera vinculada a unos personajes, que es de suponer se hallaran pertrechados de un fuerte aparato militar con el que ejercer el control y cohesión del territorio para sojuzgar y dominar grandes áreas geográficas, mediante la superioridad de sus armas, panoplia guerrera bien conocida por cierto, tanto por los materiales arqueológicos, como por esos mismos objetos grabados en las estelas decoradas, como las espadas, escudos, cascos, así como de carros tirados por cuadrúpedos (ya se trate de asnos, mulos o caballos, aunque suponemos que se tratara de estos últimos). Por esa razón se le ha atribuido a la ubicación y distribución de las estelas un carácter defensivo asociado a las rutas de pastoreo que marcarían los hitos del recorrido de las cañadas ganaderas. En tal supuesto quienes se trasladaban a otros territorios estaban ocupando unas zonas, que es de prever no les pertenecían, y por tanto se hacía necesario que los pastores fuesen defendidos de los ataques de quienes eran poseedores de las tierras en donde estos extraños se introducían con sus ganados.

En el Próximo Oriente existen ejemplos en los que las estelas marcan límites territoriales, por lo que sería interesante saber si las zonas fluviales y su entorno, o las áreas elevadas, sirvieron también aquí como marcadores de esas supuestas fronteras. M. Liverani (1988:392) se ha referido a la existencia de las estelas entre los asirios, quienes las consideraban como la "imagen de la realeza", mediante las que atestiguaban los límites de su posesión, ya que se hallaban erigidas en los manantiales del Tigris y en montañas elevadas, cercanas a las orillas del Mediterráneo. De ser así, las estelas de los tartesios podrían explicarse también como hitos con una función parecida a aquéllas, o para conmemorar una batalla, o como indicadoras de un lugar de avance en la ocupación de nuevos territorios, entre otras muchas posibilidades que aún es posible plantear.

\section{3. ¿SON DIVINIDADES GUERRERAS LAS FIGURAS REPRESENTADAS EN LAS ESTELAS?}

La hipótesis que defenderemos tiene como base la siguiente proposición. Creemos que las figuras de las estelas no representarían necesariamente a un guerrero, sino a una divinidad guerrera, o de otras muchas atribuciones. Y las armas, junto a los otros objetos que frecuentemente le acompañan, ya sean espejos, liras u otros, se corresponderían con los símbolos que les son propios, de manera que cuando se trata de estelas anicónicas, su representación tendría como finalidad la de sustituir su figuración, al tratarse de los atributos que las distinguían.

No resulta sencillo $-\mathrm{y}$ no lo ha sido tampoco en el pasado, para quienes se han ocupado de estos temas-, determinar su simbolismo, porque, como hemos dicho, es necesario contar con muchos datos sobre múltiples aspectos, sin duda relevantes, de los que carecemos por el momento, y sin los cuales no resulta posible valorar debidamente su contenido, por lo cual advertimos al lector que esta hipótesis debe ser tomada con la cautela necesaria hasta tanto no se avance algo más y pueda ser mejor contrastada con otros datos complementarios.

Es bien sabido que cuando se hace alguna propuesta distinta a las manejadas tradicionalmente, y sobre todo cuando existen planteamientos de gran raigambre ya muy consolidados, resulta primordial hacer algunas consideraciones -todas bien conocidas en la metodología arqueológica-, para buscar distintos argumentos que ayuden a reforzar la hipótesis que se propone. 
Entre ellos, desde luego, resulta imprescindible un conocimiento detallado de algunos aspectos, como el relativo a las áreas geográficas y a los lugares exactos en donde han sido halladas las estelas para valorar el contexto arqueológico y el entorno asociado a ellas, puesto que de la relectura de todos estos ítem -hechos con un planteamiento diferente a los comúnmente manejados-, es posible avanzar algo más sobre lo ya conocido.

Una de las muchas cuestiones relativas al hallazgo de las estelas decoradas - que ha terminado por convertirse en un lugar común-, es que estos monumentos, en la mayoría de las ocasiones, por no decir en todas, han aparecido - se dice- sin contexto arqueológico bien definido. Con relación a esta primera afirmación, creemos necesario hacer algunas consideraciones. Es cierto que en su entorno no se han encontrado los restos materiales característicos que suelen acompañar a otros hallazgos arqueológicos, como cerámicas, objetos líticos o metálicos, frecuentes en cualquier otro ámbito de las culturas del Bronce Final peninsular. Pero éste no siempre tiene porqué asociarse necesariamente a materiales muebles, ya que en ocasiones el objeto de estudio puede ser el propio contexto arqueológico, en este caso la misma estela, pero sobre todo el medio, y de modo singular las características propias del sitio en donde se localizaron. En este sentido conviene recordar que un buen número de estelas han aparecido en las riberas de los ríos. No precisamente en las grandes cuencas fluviales, ciertamente, pero sí en las de los arroyos, o en sus cercanías (Celestino 2001:76). Y en el supuesto de que las estelas hubieran tenido como finalidad la de sacralizar un lugar, recordar la memoria de un muerto, o conmemorar un hecho determinado, seguramente el contexto arqueológico habría que buscarlo en los ítem señalados, o en otros, como las estructuras de piedras con las que en muchas ocasiones se hallan asociadas, así como también en los imprecisos indicios arqueológicos que sugieren la realización de ritos de combustión de ofrendas o libaciones, como veremos más adelante.

Es bien cierto que la falta de control arqueológico en el momento del hallazgo de la mayoría de estos monumentos no permite avanzar gran cosa, aunque sí sabemos que muchas estelas han aparecido en zonas en las que había grandes amontonamientos de piedras, y en ocasiones también se han localizado lajas hincadas en sus cercanías que, según se desprende de algunos de los informes arqueológicos publicados, podrían haber estado dispuestas de una forma predeterminada. Por ello no conviene descartar una revisión detallada de muchos de estos aspectos, de los que es posible deducir algunas cuestiones sobre su contexto arqueológico, que quizá no fue debidamente valorado en su momento, ni tampoco con posterioridad, seguramente por la concepción misma atribuida a estos monumentos.

La aparición en el entorno de las estelas de un buen número de piedras hincadas, algunas dispuestas en círculo, nos ha hecho pensar si en algún momento pudieron haber formado parte de una estructura de la que por ahora se desconoce su finalidad, aunque bien pudieron configurar o estar integradas en lugares de culto. En algunos sitios, en donde ha aparecido más de una estela, como "Solana de la Moranilla", en Écija (Sevilla) (Celestino 2001: 422-428; nombradas como Écija I y II) uno de cuyos hallazgos -la estela IV- fue constatado por nosotros (Tejera, Jorge y Quintana 1995), pudimos documentar que se hallaba junto a otros materiales arqueológicos dentro de un amontonamiento informe de piedras, que ahora no descartamos pudiera haber formado parte de alguna estructura que las labores agrícolas y el aterrazamiento del terreno contribuirían a hacer desaparecer. Otro ejemplo de estas características está asociado al hallazgo de las estelas de "Valencia de Alcántara" (Cáceres), en donde una de ellas, la n ${ }^{\circ} 1$, se encontró en un entorno en el que había también muchas piedras, lo que nos ha hecho suponer asimismo que pertenecieran a alguna estructura igualmente desaparecida, sobre todo porque las otras dos estelas, procedentes también de este yacimiento, se hallaron aisladas y fuera de su emplazamiento primitivo, pero casi en el mismo paraje que la anterior, como la tercera, localizada en una loma no lejos de las otras (Almagro 1966: 112 y 114). Por otra parte, la estela de "Hernán Pérez", encontrada en un entorno fluvial, en la que había otras cuatro (Almagro 1972: 86), se halló junto a un buen número de lajas de piedras de gran tamaño (Almagro 1974: 32), de las que en ningún caso sabemos si formaron parte de una estructura con forma definida. Otro ejemplo significativo a tener en cuenta son las estelas de "San Martinho" (Castelo Branco). En este yacimiento se documentaron tres formando un conjunto, situado en una zona elevada, en el sitio denominado la loma de "San Martinho", lugar que domina un importante eje de comunicaciones relacionado con la sierra de la Estrella, al norte; la de Gata al noroeste; y el río Tajo al este y sur. Otro hallazgo que entendemos muy destacable asimismo es la estela de "Cabeza de Buey (II)", sobre la que S. Celestino en el catálogo de su importante monografía de estos monumentos dice que "la piedra apareció hincada y totalmente cerrada. Al lado del lugar del hallazgo, a no más de $20 \mathrm{~m}$ encontró una acumulación de piedras que formaban círculos, tres o cuatro, unidos entre sí. (...) [el lugar] se encuentra lleno de piedras en forma de estelas pero sin decorar en un radio aproximado de $30 \mathrm{~m}$ cuadrados. El lugar está en una 
pequeña elevación que hoy se presume artificial" (Celestino 2001:364-365). En una excavación de urgencia realizada en ese sitio, en 1992, los resultados fueron, según sus excavadores, completamente estériles. A la vista de lo anterior cabría pensar, sin embargo, que no se trataría en realidad de un yacimiento al que se le debería definir de ese modo, si como pensamos la estela, las lajas y los amontonamientos de piedras, pudieron formar parte en realidad del contexto arqueológico.

Con características similares cabe destacar, igualmente, el hallazgo de las estelas "Torrejón El Rubio" I y II, que fueron localizadas juntas, al margen de otras dos recogidas en el mismo municipio que se hallaban jalonando el río Tajo. Por su parte, la estela de "Las Herencias" (II) fue exhumada en la campaña de excavaciones del poblado protohistórico homónimo, junto al Arroyo Manzanas, concretamente en el sector exterior IV. Según los informes arqueológicos, la estela había sido colocada en el interior de una construcción de planta cuadrangular, hecha de tapial sobre un pequeño zócalo de piedra. La cultura material del poblado indica que su origen puede remontarse al Bronce Final (en Celestino 2001: 424). Análogos conjuntos de losas y piedras han sido verificados junto a las estelas de "San Martín de Trevejo", "Navalvillar de Pela" (al lado de seis lajas cortadas por uno de sus lados, ligeramente alisadas por una de las caras y estrechadas en la parte inferior para poder ser hincadas en la tierra), "Cabeza del Buey” II y en "Zarza Capilla" (ibídem, 279-280). También en zonas periféricas al área nuclear de localización de las estelas han podido documentarse agrupamientos de tales monumentos. Nos referimos, por ejemplo, a la estela de "Figueira", muy próxima al cabo de San Vicente. Aunque los datos sobre su hallazgo son contradictorios, una de las versiones señala que apareció hincada en un lugar dominado por grandes lajas no vinculadas a un campo de cistas (ibídem, 443). Más segura es la información disponible sobre la estela de "Substantion" en Montpellier, recuperada junto al oppidum ibérico del mismo nombre. Fue descubierta en el año 1916 sobre un amontonamiento de piedras y cenizas (ibidem, 449).

Nos ha parecido pertinente señalar estos hechos por cuanto son muchos los sitios en los que se hallan grandes conjuntos de losas, como sucede también en "Quintana de la Serena", muy próxima al santuario de "Cancho Roano", edificio en el que, como es bien sabido, una estela decorada en forma de betilo (muy similar por cierto a la de "Magacela") fue reaprovechada como umbral en la entrada. Según su excavador, como primer escalón de este acceso fue empleada otra laja con clara forma de estela, planteando la posibilidad de que ambos soportes procedieran del mismo lugar, probablemente muy cercano, a tenor de las dimensiones de las losas (Celestino 2001: 280). Llegados a este punto, conviene señalar la llamativa vinculación que parece existir entre algunas estelas y determinados lugares de culto que presentan registros arqueológicos del Bronce Final o del período orientalizante. Al mencionado complejo religioso de Cancho Roano (en cuyo nivel más antiguo se exhumó una cabaña de tendencia ovalada y parcialmente cortada por la cimentación de la construcción "C", que se fecha en el Bronce Final), habría que añadir otros yacimientos en los que se pueden relacionar estelas y construcciones de índole religiosa, tales como Carmona, Montemolín, La Mata de Campanario (cerca de Magacela), o el singular edificio hipogeo de Pocito Chico (Puerto de Santa María, Cádiz). ¿Formaron parte estos monumentos pétreos de los primitivos lugares de culto del Bronce Final?, ¿fueron el embrión a partir del cual adquirieron estos lugares su carácter sacro en momentos posteriores?

Lo expuesto nos ha hecho suponer, aunque sólo sea una hipótesis a confirmar, que muchas de las estelas -que como sabemos, en la mayoría de las ocasiones iban hincadas en el suelo por la forma en la que estaba preparada la base-, no se hallarían aisladas, sino que podrían haber estado rodeadas de lajas de piedras formando algún recinto que las circundaba -es posible pensar incluso, como hemos visto, que algunos fueran de forma circular-. Y en otros casos también estarían rodeadas por amontonamientos de piedras, como majanos, o estructuras a manera de túmulos. Pero sobre todo -y esto resulta especialmente relevante-, muchas estelas parecen conformar conjuntos, hasta ahora no ciertamente bien definidos. A partir pues de estos supuestos, quizá no sería oportuno generalizar, como se ha hecho, sobre la falta de contexto arqueológico en estos monumentos. Creemos necesario, por el contrario, revisar muchas de estas cuestiones, en la creencia de que aún se pueda inferir otros datos de los sitios en los que se han hallado, por si fuera posible recuperar alguna información para avanzar nuevas hipótesis, o enriquecer las ya conocidas, a pesar de que, como es bien sabido, una parte importante ha desaparecido, pero contamos, sin embargo, con un buen número de datos bien sistematizados en las obras de síntesis de M. Almagro (1966), E. Galán (1993) y S. Celestino (2001), lo que puede facilitar un replanteamiento de todos estos problemas con la seguridad de enriquecer algo más lo ya conocido.

Abundando en la idea de que los conjuntos de losas, decoradas o no, formaran parte de lugares de culto al aire libre, creemos oportuno traer a colación nuevamente la asociación de algunas estelas a restos de 
fuegos y cenizas, tal y como se sugirió ut supra. Puesta en entredicho su pertenencia a restos óseos humanos, cabría preguntarse sobre la posibilidad de estar ante verosímiles ofrendas $\mathrm{u}$ hogueras rituales, bien atestiguadas en ambientes funerarios tartésicos (Torres 1999: ver fundamentalmente 153-154). Tales restos de fuego han podido documentarse en las estelas de "Solana de Cabañas", "Granja de Céspedes", "Córdoba” II, "Badajoz" o "Substantion", como ejemplos más conspicuos. Pero también es probable que se realizaran otros ritos que pudieron no dejar rastro arqueológico, tales como libaciones de agua, leche $\mathrm{u}$ otros productos. Un texto de Estrabón (III, 1, 4) en el que se describe el llamado Hieron Akroterion (Cabo de San Vicente) arroja luz sobre este particular. El pasaje ha sido interpretado por los especialistas como un testimonio literario del culto marino fenicio a dioses como Melqart, Baal Hamón o Baal Safón (Alvar 1999: 393, con bibliografía ${ }^{3}$ ). Sin embargo, Estrabón es claro cuando afirma que la costumbre es indígena: "Pero en lo que se refiere al cabo mismo, que se adentra en el mar, Artemidoro (que visitó el lugar, según dice él) lo compara con un barco (...) Pero en cuanto a Heracles, según dice, no se ve un templo suyo en el cabo (como erróneamente afirma Éforo) ni un altar dedicado a él, o cualquier otro dios, sino sólo piedras en muchos lugares, en grupos de tres o cuatro, las cuales de acuerdo con una costumbre de los nativos, hacen girar las personas que visitan el lugar, y luego, después de derramar una libación sobre ellas, vuelven a colocarse en su sitio. Y añade que no es lícito ofrecer sacrificios alli, y tampoco, de noche, poner los pies en el lugar, porque los dioses, según dice la gente, lo ocupan en aquel momento; más los que vienen a ver el lugar pasan la noche en un pueblo vecino, y luego entran en el lugar de día, llevando agua con ellos, porque allí no hay agua" (las cursivas y negritas son nuestras; traducción en Fernández Castro 1997: 265). Como dato curioso, justo es recordar aquí que la estela más occidental de todo el conjunto fue hallada, posiblemente formando un conjunto con otras lajas, en la aldea de Figueira, en el municipio de Budens, a sólo 1 kilómetro de la playa de Salema, junto al cabo de San Vicente, el Promontorio Sagrado de las fuentes escritas (Celestino 2001: 443).

En esta misma línea interpretativa, existen otros muchos aspectos asociados con las estelas que quizá convendría revisar, como algunos grabados que aparecen en las losas y que hasta ahora no han sido bien estudiados. Nos referimos a la presencia, en muchas de ellas,

3. Una sugestiva interpretación del texto desde la óptica indoeuropea en García Quintela (2001: 40-44). de una serie de pequeñas cúpulas o cazoletas, como las aparecidas en la de "Fuente de Cantos" y "Magacela" en Badajoz; o en la de "Pedro Abad", y en la de "Córdoba" I (concebida para ser colocada en posición horizontal; ver Celestino 2001: 435) y en algunas otras, de las que desconocemos su función. Estas cúpulas o cazoletas suelen ser comunes en estelas y paneles rupestres de otros contextos culturales (ver para otras sociedades europeas de la Edad del Bronce, Harding 2000: 332 ss., con bibliografía), como también en las paredes grabadas en recintos cultuales. Pensamos si pudiera tratarse de un fenómeno similar a las conocidas en otros lugares destinados al culto, generalmente asociadas a sitios en donde se realizan rituales para derramar líquidos, ya sea agua, sangre, leche u otros, destinados a celebraciones propiciatorias a las divinidades a quienes se les solicita algún beneficio.

En el supuesto de que estos monumentos desempeñaran cualquiera de las funciones referidas, nos parece que la estela habría de entenderse como parte imprescindible del propio contexto. Y en el caso de que sirvieran como conmemoración funeraria de la persona enterrada -esta es una de las hipótesis más frecuentemente manejadas-, se podría suponer que este hito recordaría el lugar en donde se depositaron las cenizas del muerto o la ofrenda votiva que, como veremos más adelante, se ha defendido como una de las hipótesis -que compartimos- por la que después del rito crematorio sus restos incinerados se echarían a las aguas. Y en ese caso, sería la propia estela $y$, naturalmente el río o el lugar con agua que le sirvió de lecho funerario, los que formarían parte del contexto arqueológico, ya que como muy bien ha señalado S. Celestino en su monografía (2001), estos monumentos han aparecido prácticamente en su totalidad en zonas cercanas a áreas fluviales.

Uno de los muchos problemas relacionados con la sociedad tartésica de época preorientalizante, es la falta de datos sobre sus enterramientos. La ausencia de restos funerarios de esta etapa, ha dado pie a la propuesta de algunas hipótesis de verdadero interés, de las que nos gustaría destacar la formulada por $\mathrm{M}^{\mathrm{a}} \mathrm{Be}$ lén y J. L. Escacena (1995, con bibliografía), quienes defienden que en esta etapa los tartesios incineraban a sus muertos, como así sucede en la fase orientalizante posterior. Según estos autores, después de que los muertos fueran incinerados, sus cenizas se esparcían en las aguas de los ríos, y con ellos los objetos que les eran propios, por lo que los hallazgos de espadas, fíbulas, regatones de lanzas, que formaban parte del depósito de la Ría de Huelva, pudieron formar parte de la panoplia guerrera de los personajes allí enterrados. Esta hipótesis encuentra argumentos para su contraste 
en el hallazgo de espadas y otras armas asociadas a las aguas, por lo que cabría pensar del mismo modo que las estelas localizadas en el entorno de zonas fluviales se relacionaría de igual modo con los sitios en los que fueron vertidas sus cenizas, de modo que las estelas, como ya habíamos señalado, pudieron servir de hito funerario con el que se señalaba el lugar en donde se habían depositado los restos del muerto. Una cuestión relevante para el mejor conocimiento de estas manifestaciones culturales es la de asociar los hallazgos de las estelas con todos los yacimientos y los materiales arqueológicos del Bronce Final encontrados en el entorno más próximo de las estelas, y de los que cabría destacar, sobre todo las armas, por si estos datos sirvieran para enriquecer su contenido (Ruiz-Gálvez 1995 y 1998). Y aunque estos aspectos se han tenido en cuenta a la hora de plantear las distintas propuestas, creemos que aún se pueden hacer algunas aportaciones, partiendo de otros supuestos, como el que aquí proponemos.

Otro aspecto que consideramos imprescindible manejar para el estudio y análisis de las estelas -y en este caso para la hipótesis que defendemos-, tiene que ver con la comparación de fenómenos parecidos, tanto con relación a otros ambientes culturales próximos de la protohistoria de la Península Ibérica, o en algunos lugares del Mediterráneo, como las de Cerdeña; o con las del Norte de África, en este caso las estelas líbico-beréberes, pero también y sobre todo, las de las necrópolis y los santuarios púnicos magrebíes.

Debemos también señalar el problema de que la mayor parte de las estelas se encuentran ubicadas no en la zona nuclear tartésica -como parecería más lógico- sino en su hinterland inmediato. A esto sería conveniente añadir que en las estelas, hasta ahora consideradas más antiguas, la panoplia armamentística es bastante anterior a las fechas teóricas en que se las quiere situar, lo que como mínimo merecería un intento de explicación.

Otros muchos hechos asociados con estos monumentos que son, sin duda de gran interés, pero que no resulta fácil explicar, están relacionados con el problema de qué es primero si la presencia de la figura humana, o el de su aniconismo. Similares problemas son también los de saber cómo les afectaron los cambios, ya fueran los propios de sus concepciones religiosas en su desarrollo cultural, o los que tuvieron lugar como consecuencia del contacto con los pueblos del Mediterráneo. Son cuestiones todas del máximo interés, sin duda, pero que no resultan fáciles de entender, por lo que por el momento sólo alcanzamos a plantearlas como interrogantes y como futuras líneas de indagación.

\section{EL PROBLEMA DE LAS FUENTES LITERARIAS Y ARQUEOLÓGICAS}

A continuación haremos referencia a unos pocos datos existentes en las fuentes literarias y arqueológicas para tratar de fundamentar nuestra hipótesis, a pesar de que, como hemos señalado, uno de los muchos problemas para el conocimiento del mundo tartésico es, sobre todo, la escasez de datos relativos a su cosmogonía y su pensamiento religioso, sin el que, como hemos señalado, no resulta fácil aventurar grandes cosas, ya que la información es muy parca y poco explícita, y se halla impregnada además por una fuerte carga de etnocentrismo, que ayuda poco a discernir lo propio de esta sociedad, de lo que puede ser sólo una traslación de manifestaciones religiosas de los griegos y, en su caso, de los romanos, de quienes proceden, en su mayoría, las fuentes sobre esta cultura. Esta escasez plantea además un doble problema. Por una parte, la poca relevancia de la información que no ayuda a obtener evidencias de interés sobre este mundo, y asimismo la dificultad para contrastar lo poco que se ha conservado.

De esos datos conocemos en las fuentes literarias una referencia contenida en la obra de Silio Itálico sobre Argantonio, a quien este autor hacía vivir doscientos años y lo consideraba un rey guerrero, según J. Caro (1986: 210), recogido en la nota 23 del cap. II dedicado al estudio de la realeza tartésica. La información del poeta latino introduce una idea importante sobre esta figura al definirlo como un guerrero, dato que por cierto no figura en otros autores.

En casi todas las fuentes literarias se presenta a Argantonio como un rey representativo de un poder centralizado, como se desprende, entre otros documentos, del texto de Herodoto sobre la alianza de amistad celebrada con los griegos: "Los habitantes de Focea, por cierto, fueron los primeros griegos que realizaron largos viajes por mar y son ellos quienes descubrieron el Adriático, Tirrenía, Iberia y Tarteso. No navegaban en naves mercantes, sino en pentencónteros. Y, al llegar a Tarteso, se hicieron muy amigos del rey de los tartesios, cuyo nombre era Argantonio, que gobernó Tarteso durante ochenta años y vivió en total ciento veinte. Pues bien, los foceos se hicieron tan grandes amigos de este hombre que, primero, les animó a abandonar Jonia y a establecerse en la zona de sus dominios que prefiriesen; y, posteriormente, al no lograr persuadir a los foceos sobre el particular, cuando se enteró por ellos de cómo progresaba el medo, les dio dinero para circundar su ciudad con un muro. Y se lo dio a discreción, pues el perímetro de la muralla mide, efectivamente, no pocos estadios y toda ella es de bloques de piedras 
grandes y bien ensamblados" (las cursivas son nuestras; Herodoto, I, 163, [1984]: 223-224). Las relaciones de ambos, a juzgar por lo que dice el historiador griego, cuando alude a él como "rey de los tartesios", es un buen argumento que podría corroborar la hipótesis de una autoridad política centralizada en Tarteso en una etapa previa al contacto con los pueblos mediterráneos. Ello implicaría que podría tratarse ciertamente de un rey, probablemente histórico en sus orígenes, pero que por su carisma y valentía como guerrero, $u$ otros atributos, sería recordado en la memoria histórica de los tartesios seguramente por haber sido heroizado, y sublimada su figura; y al que además se le habría aureolado con el atributo de la fecundidad, según se deduce de las alusiones a su próspero gobierno en el territorio del que es Jefe Supremo. E. Benveniste (1983: 254) destaca la importancia que en las sociedades indoeuropeas se le concedía a la fecundidad y a la felicidad de los reyes. Y seguramente es en este mismo sentido en el que podría explicarse la alusión a la longevidad de Argantonio, por lo que no descartamos que en el citado texto de Herodoto, estos conceptos se traspolaran también con igual contenido al rey de los tartesios. Por otra parte, la iconografía de época orientalizante reforzará en el imaginario tartesio la asociación entre fecundidad, poder real y aristocrático (Olmos 1996; Fernández Rodríguez 1996). Asimismo, no nos parece ocioso traer a colación aquí la forma fálica que se le otorgó a la estela de granito de "San Martinho II", en la que fue representada una escena cinegética, en concreto una cacería de ciervos (Celestino 2001: 59).

La referencia a la longevidad de Argantonio en el texto sobrecitado, aparece reiterada de forma diversa y con explicaciones de distinto tipo, atribuyéndole un carácter histórico que no tiene fácil justificación. En todo caso, parece probable que quienes recogieron la tradición de este personaje debieron superponer dos niveles de información, el de la leyenda y el de los hechos históricos, sin que descartemos tampoco, como probable, que lo transmitido en tales fuentes pudiera referirse en origen a un rey mítico -lo que parece desprenderse también de las informaciones que sobre él conocemos en otras fuentes-, aunque la tradición historiográfica haya pretendido, sin embargo, presentarlo como un rey al que se le ha querido encuadrar incluso en la secuencia cronológica del proceso histórico-cultural de Tarteso.

Además de la citada referencia de Silio Itálico sobre la consideración de Argantonio como un rey guerrero y su probable asociación también con uno de carácter mítico, conviene traer a colación asimismo el hallazgo de un grafito en el que se halla grabado el nombre de una divinidad, Niethos. Fue localizado en Huelva, en el año
1983, adonde llegaría seguramente por las relaciones comerciales de los griegos con Tarteso. Está formado por ocho letras griegas arcaicas, que se fechan en la primera mitad del siglo VI a.C. El nombre que figura en él es un teónimo, que no pertenece al panteón griego, por lo que M. Almagro Gorbea lo ha relacionado con una divinidad local, a la que considera el primer documento en el que se habla de un dios tartésico ${ }^{4}$.

Este teónimo no aparece en la lengua de Tarteso, por lo que el citado profesor lo relaciona con el de $\mathrm{Ne}$ ton, documentado en $\mathrm{Acci}$, ciudad prerromana del sur de la Península Ibérica, asociándolo con el teónimo Néit, que podría traducirse por "el guerrero", el "Héroe", "el guía", "el radiante", o como el dios de la batalla. El citado investigador (2004: 204), cree que en ese caso el Niethos podría significar, en el contexto tartésico, "el guerrero" o el "que brilla". Para explicar en esta cultura la existencia de tal divinidad alude a las figuritas de bronce conocidas como smiting gods, relacionadas con el dios del sol y de la guerra, y en su origen fenicio con Reshef, Melkart o Baal. La presencia de los smiting gods en el ámbito fenicio-tartésico parece un buen camino para tratar de buscar en ellos alguna tradición autóctona relacionada con posibles representaciones de una divinidad guerrera con la de las citadas figuras, encontradas en el entorno de los santuarios gaditanos, lo que podría hacer pensar en una posible asimilación o superposición de la tradición fenicia a la tartésica, como sucede también, entre otros, con algunos exvotos ibéricos de bronce o la figura de un personaje blandiendo una falcata que aparece en uno de los relieves del monumento funerario de "Pozo Moro" (Chinchilla, Albacete ${ }^{5}$, que fue considerada asimismo una divinidad, aunque otras lecturas lo identifican como un héroe mítico (Olmos, 1996; Fernández Rodríguez, 1996). Otra cuestión de gran interés planteada por M. Almagro Gorbea (2004: 201) con relación a esta divinidad, es si asociado con ella existió en el puerto de Huelva algún santuario fluvial. Sólo como interrogante cabría preguntarse si en ese caso el depósito de armas y objetos encontrados en la ría del Odiel estuvo relacionado de algún modo con ese supuesto santuario. A

4. Hace algunos años que M. Ruiz-Gálvez planteó la posibilidad de que el rito de depositar armas en las aguas pudiera estar relacionado con el dios céltico Bormánico, protector de las aguas, especialmente las termales, teónimo del que podría quedar huella en la localidad y embalse de Bornos, en el curso medio del río Guadalete y, por consiguiente, cerca del Lago Ligustino (en Olmos 1987: 8-9). Para J.M a Blázquez (2001: 159), Deva es el único teónimo indígena (de procedencia céltica también), conocido en la Bética. Deriva de deiva, la "divina", diosa de carácter acuático.

5. Ver el estudio detallado sobre la iconografía del monumento turriforme de Pozo Moro en F. López Pardo. 
este respecto, en los últimos años han sido exhumados en el casco urbano onubense, particularmente en una pequeña área comprendida entre las calles del Puerto, Plaza de Quintero Báez y Méndez Núñez, algunas estructuras arquitectónicas y materiales arqueológicos de notable interés religioso que han sido interpretados como evidencias de lugares de culto indígenas, griegos o empóricos (ver los trabajos, entre otros, de Garrido y Orta 1994; Garrido 1998; Osuna, Bedia y Domínguez 2001; Domínguez 2001). Estas y otras cuestiones tratadas aquí son, sin duda, relevantes, pero como decíamos más arriba, han de ser aún debidamente contrastadas con otros muchos datos sobre los que ahora no nos podemos pronunciar.

En la bibliografía arqueológica antigua sobre las estelas no son muchas las opiniones en las que se haya expresado una propuesta similar a la que nosotros hemos expuesto aquí, aunque existen, sin embargo, algunos datos relevantes sobre los que nos ha parecido oportuno referirnos, como lo sostenido por Tavares de Proença, cuando dio a conocer la estela de "San Martinho I" en Castelo Branco (Almagro 1966: 32), al decir que "su edad, su utilidad y la significación de los grabados son para mí un misterio. Yo creo, sin embargo, poder concluir que, en su aspecto, ellos han sido objeto de un culto". Resulta sugerente la proposición de este autor, por su originalidad, ya que son muy poco frecuentes las sugerencias de estas características que se conocen sobre el simbolismo de estos monumentos.

M. Almagro Basch, que en su momento llamó la atención sobre la propuesta de Tavares al referirse a la estela de "San Martinho III", encontrada en el lugar de Mercoles, también en Castelo Branco, que formaba parte de un conjunto, llega a decir que en el sitio en el que apareció este grupo de estelas grabadas "debió de existir no lejos una necrópolis o santuario donde debieron de depositarse estas estelas que, como veremos, se nos aparecen con frecuencia agrupadas en varios lugares" (Almagro 1966: 39). La sugerente reflexión de este investigador posee para nosotros un gran valor, no sólo por coincidir en algunos aspectos con la propuesta que hacemos, sino por señalar que con suma frecuencia, como hemos indicado más arriba, las estelas aparecen en efecto formando grupos.

Con relación al trabajo ya citado del prof. Almagro Gorbea acerca de un teónimo céltico encontrado en Huelva, se vuelve de nuevo a poner de relieve una cuestión sobre la que mucho se ha hablado, pero que está falta aún de una mejor definición. Se trata del posible sustrato indoeuropeo de la cultura tartésica, ya que todo lo relativo a este tema está rodeado de una fuerte polémica, al que se acude a él sólo de manera esporádica, y sin que en ningún momento se haya planteado con el rigor y la profundidad que el hecho merece, por lo que no existe aún un estudio bien documentado y contrastado, a pesar de tratarse, a nuestro juicio, de una cuestión del máximo interés.

A este tema, ya se refirió M. Almagro Basch (1966) con ocasión del hallazgo de la estela de Carmona, la primera de las encontradas en el ámbito del Guadalquivir, para quien esto significaba una prueba evidente de la presencia en Andalucía de los “cempsos", citados en las fuentes, y que él relacionaba con gentes indoeuropeas presentes en la región tartésica-turdetana. En esta misma línea interpretativa se pronunció casi veinte años después F. P. Curado, con motivo de la publicación de las losas de Baraçal y Foios (1984 y 1986), para el que las gentes que erigieron las estelas fueron poblaciones indoeuropeas preceltas, desplazadas desde Europa Central.

Todo lo anterior sirve para llamar la atención una vez más sobre este problema del que si contáramos con datos mejor elaborados, y desde luego con más información, quizá podríamos vincular algunas manifestaciones tartésicas con los mitos y la religión indoeuropea, en especial todo lo referido a los llamados dioses soberanos y guerreros de su cosmogonía, lo que de seguro ayudaría a entender mejor algunas cuestiones de las que venimos hablando y sobre las que por el momento no podemos manifestarnos con la seguridad que nos gustaría.

Como hemos visto, y así se halla suficientemente explicitado en toda la literatura arqueológica, a las estelas se les conoce, entre otras denominaciones, con la adjetivación de "guerreros" por la presencia de una figura humana, generalmente acompañada de su panoplia. Pero, sin embargo, en un buen número de ellas no aparece una sola figura, sino varias, y en otras ocasiones, una pareja, como en "San Martinho I", "Zarza Capilla III", "Valdetorres I", "Alamillo" o "El Viso III, IV y VI", entre otras. Cuestión que de nuevo plantea algunos problemas del máximo interés por la falta de datos, como hemos dicho, para obtener una lectura e interpretación correctas sobre la cosmogonía y la religión de los tartesios. Por esa razón lo que planteamos a continuación lo hacemos sobre la comparación con hechos de las mitologías de las sociedades indoeuropeas, entre las que se conoce un "mito de origen" basado en la existencia de los "gemelos", del que se conocen dos variantes, aunque ambas coinciden en que "el mundo comienza con una pareja de gemelos: *Manu, 'hombre' y *Yemo 'gemelo'. *Yemo es el primer rey mientras que *Manu es el primer sacerdote, en el transcurso del mito *Manu mata a su hermano, de este modo, realiza el primer sacrificio. 
Como resultado de este hecho, se crea el mundo, ${ }^{*}$ Manu conforma la Tierra y el cielo así como las tres clases sociales a partir del cuerpo de su hermano" (Lincoln 1991: $108)^{6}$. No pretendemos con este ejemplo establecer, en ningún caso, una comparación mecánica de estos hechos con las parejas que también aparecen formando parte de la iconografía en unas pocas estelas tartésicas. Sólo queremos llamar la atención sobre este aspecto que es uno más de los que plantean problemas para su interpretación, pero que por ahora resulta muy difícil avanzar algo sobre ello, aunque nos ha parecido oportuno ponerlo de manifiesto para una futura y necesaria discusión sobre todos estos temas.

\section{EL CONTEXTO ARQUEOLÓGICO}

Nuestra propuesta de que la figuración humana grabada en las estelas podría ser la representación de una o de unas divinidades guerreras, no descarta en ningún caso que pudiera tratarse también de la representación de héroes divinizados o antepasados heroizados (RuizGálvez y Galán 1991), cuestión que asimismo convendría tener en cuenta, ya que una y otra no entran necesariamente en contradicción.

En párrafos anteriores ya nos hemos referido a una de las hipótesis que en el pasado sirvió de explicación para las estelas, al considerarlas marcadores de tumbas, hecho que no habría porqué desechar siempre, ya que en nuestro supuesto, si tal figuración representara una divinidad, su presencia en una estela reforzaría aún más esa idea, ya que de ese modo la memoria de la persona a la que se recordaba - es de pensar que se tratase de un guerrero-, se hallaría preservada y protegida por la presencia cercana de una divinidad, al ser la función apotropaica de protección al muerto, una atribución primordial de las divinidades, como se certifica de un modo fehaciente en las necrópolis e iconografía ibérica (Fernández Rodríguez 2005:219) .

Como ejemplo de lo dicho, cabría traer a colación una de las estelas más singulares de las conocidas hasta ahora. Se trata de la de Ategua (Córdoba), en donde está grabada una escena que describe la muerte de un guerrero, y para la que el prof. Bendala (1977) le encontró paralelismos, bien evidentes como ha sido suficientemente divulgado, en representaciones similares de las cráteras del Dypylon de Atenas. Presidiendo

6. Véase sobre estas cuestiones el reciente trabajo de Kristiansen y Larsson (2006:289 y ss.), en donde hacen un estudio detallado de este problema, sobre el que asimismo nosotros tratamos de analizarlo en la cultura tartésica. la escena se halla una figura, interpretada como representación del guerrero, que se destaca y singulariza en la escena por ser una imagen de tamaño mayor que el resto de lo figurado en ella. Según nuestra propuesta se podría pensar, en cambio, que en lugar de la representación del guerrero pudiera tratarse de una divinidad protectora que de manera destacada contempla y ampara lo que en ella está teniendo lugar.

Uno de los aspectos que se desprende del estudio de las estelas decoradas es, sin duda, su carácter polisémico, lo que ha dado pie a las distintas hipótesis sobre su interpretación, por lo que caben aún otras muchas explicaciones, a medida que se avance en el conocimiento de la sociedad tartésica. Así, la lectura más común sobre su iconografía es la de relacionar las armas en ellas representadas, espadas, lanzas, escudos, cascos, como instrumentos de combate, vinculadas a la lucha, expresando una idea de protección y defensa, pero también un símbolo de ataque. Toda esta panoplia guerrera se complementa, en muchas ocasiones, con la figuración de un carro. La presencia de todos estos elementos asociados a una figura humana parece no dejar ninguna duda para interpretar esta iconografía como la propia de un guerrero.

Sin embargo, sabemos muy bien que en muchas culturas las armas, como las representadas en las estelas, poseen asimismo un carácter ritual cargado de un fuerte simbolismo por lo que se utilizan en ceremonias -muchas de ellas relacionadas con el mundo de la guerra-, como las empleadas para construir el tropaion en el campo de batalla o las que se destinan a los santuarios (Gabaldón 2004:126). El escudo es en este caso, y según los textos clásicos, la pieza de armamento que más se dedicaba a los dioses, a quien Lonis (1979: 158-160) le ha atribuido esta predilección por su especial significado y un elevado valor simbólico al decorarse con motivos emblemáticos y apotropaicos. Y no está de más recordar los paralelos mediterráneos de carácter votivo que se han esgrimido para los escudos con escotadura en forma de V, grabados en las estelas del Suroeste, hallados en lugares como Idalion y la necrópolis de Paleophapos (Chipre), el Monte Idda (Creta) o los santuarios griegos de Delfos o del Heraion de Samos (recogidos en Celestino 2001: 144 ss.). Como el escudo, el yelmo, además de ser un arma defensiva (pasiva, en este caso), fue dotado de connotaciones simbólicas (Olmos 1987 y 1988). El casco, por su parte, se decoraba siguiendo una finalidad ornamental, pero también emblemática, simbólica y táctica. Por lo que respecta a los cascos con cuernos, es bien conocido que se asocian en algunas culturas antiguas con dioses o con guerreros que 
participan en ceremonias rituales. Es el caso de las escenas recreadas en el arte rupestre protohistórico escandinavo o de las figurillas de bronce documentadas en estas regiones y en Cerdeña (Harding 2003: 286). El uso del casco con cuernos (de bóvidos, como sucede con los grabados en las estelas hispanas) fue característico también de las divinidades del mundo céltico, en el que se simbolizaba la fertilidad, la virilidad y la agresión, el poder en otras palabras (Marco 1994: 333, nota 57 con numerosos ejemplos; para el mundo mediterráneo y próximo-oriental véase Gracia 2003: 199200; Kristiansen y Larsson 2006: 366-370). El prof. Bendala (2000: 76-77) señala que los cascos con cuernos de grandes dimensiones, como es el caso de la estela de "Fuente de Cantos" (Badajoz), son expresión de sobrehumanidad, atributos de dioses y héroes ${ }^{7}$. El escudo y el casco, tal y como lo testimonian las fuentes escritas y los datos arqueológicos, son las armas que más se consagraban a las divinidades. Y por último, la espada que tenía un significado mítico importante, como sucedía, a título ilustrativo, en numerosas sociedades europeas del Bronce Final y del Hierro, o en el mundo micénico, en donde poseyó un valor simbólico mucho más destacado que el de los periodos arcaico y clásico posteriores.

Además de las armas habría que señalar los otros objetos que también suelen figurar en las estelas, los espejos (de posible simbología solar), instrumentos musicales, como la lira, entre otros, que, como es bien sabido, en muchas culturas tienen un simbolismo asociado con sus divinidades. Nos referimos al caso ejemplar del dios Apolo, al que se le vincula la lira, la cítara y el arco. Algunos autores han querido ver en estos símbolos dos de las tres funciones que organizan la ideología indoeuropea. La función sagrada de la comunicación entre los hombres y los dioses, expresada a través de los instrumentos musicales, y la violencia guerrera representada por el arco en tensión (que también hace de él un dios protector). La lira y el arco simbolizan, en síntesis, los dos modos de acción fundamentales del dios griego. La lira, además, está vinculada a la función oracular. De esta manera el dios puede abarcar, dentro del campo politeísta heleno, desde funciones temibles relacionadas con la muerte, el terror y el sacrificio, hasta el papel de mediador, de comunicación armónica entre los dioses y los hombres (Bruit y Scmitt 2002: 165-169; sobre su carácter sacrificial es fundamental la monografía de Detienne 2001).

7. Sobre el carácter del simbolismo divino de los cascos de cuernos en las culturas del Próximo Oriente, ver Celestino y López (2004: 93-108 y 2006: 89-101).
La iconografía de las estelas podría en efecto ser interpretada como la representación de un guerrero, y las armas como algo propio de su panoplia; y los objetos que lo acompañan como símbolos de prestigio; pero del mismo modo -y en función del carácter polisémico señalado y de lo expuesto en páginas anteriores-, se podría pensar que esta iconografía perteneciese también a hechos simbólicos propios de un lenguaje relacionado con la divinidad, que por ahora no alcanzamos a conocer bien. No entendemos, pues, dichas iconografías como decorativas, de un cierto significado religioso y funerario, sino que, en muchas de las estelas, nos encontramos ante una iconografía netamente sagrada, que nos introduce de lleno en el ámbito de lo imaginario, en la que se representa a los dioses locales y narraciones míticas que justifican modélicamente ritos y acciones sociales (iniciaciones, muertes, cacerías, ceremonias religiosas, etc.). La presencia en numerosos monumentos de figuras antropomorfas (que presentan y repiten fórmulas de expresión idealizadoras y gestualidades concretas), no representan, a nuestro juicio, una mecánica proyección sustitutoria de la realidad social (la de las élites del Bronce Final del Suroeste peninsular, como en tantas ocasiones se ha planteado), sino que nos ofrecen las imágenes autóctonas de los dioses, de los héroes o de los antepasados míticos ${ }^{8}$.

Otro de los interrogantes a resolver, es si se trataría de divinidades de cometido general, cumpliendo funciones diversas en la estructura del panteón, o si estamos ante dioses tópicos, de funciones concretas, tales como presidir los puntos de agua (principalmente los arroyos) a los que se asocian de forma mayoritaria las estelas. A tenor de los elementos ideográficos grabados en ellas (cascos con cuernos, liras, espejos, carros, arcos y otras armas, etc.), de algunas escenas, y de la vinculación al agua de una buena parte de estas losas, nos atreveríamos a establecer como hipótesis la posibilidad de estar frente a dioses generales, señores en sentido amplio de la naturaleza fértil, protectores ancestrales del agua, relacionados con la salud (el ciclo de la vida se resume y simboliza en el agua); pero también, bajo su aspecto temible, dioses de la guerra, de las iniciaciones guerreras y de otros ritos de paso como la muerte (como refleja quizás la estela de "Ategua"). Es posible también que los conjuntos de estelas y losas descritos

8. Según algunos autores (Molinos et alii 1998: 328 ss), el guerrero rodeado o flanqueado por un grifo y un león grabado sobre una placa de marfil de Bencarrón, no sería un héroe, sino una divinidad. Los animales en esta placa se someterían así al dios masculino. En otra placa de idéntica procedencia, pudo plantearse la caza de cérvidos. Al decir de estos investigadores, se trataría, en suma, de las imágenes de auténticos dioses que se presentan como dominadores de la naturaleza (al modo del Despotes Theron o también la Potnia Theron). 
anteriormente, los ríos y otros cursos fluviales (como certifican asimismo los depósitos rituales acuáticos, así como otros hallazgos aislados y depósitos terrestres), desempeñasen un importante papel en el acceso a la jefatura o al estatus de privilegio (lo mismo que en el proceso de territorialización perfectamente planteado por Ruiz-Gálvez 1995 y 1998), en una sociedad como la tartesia del Bronce Final, en la que el jefe o el hombre poderoso se distingue por poseer y controlar las fuerzas sagradas (ideas contenidas en Díez de Velasco 1998).

Sobre las interpretaciones de las estelas, y en el caso de que se afianzara en sucesivos trabajos la hipótesis de una supuesta divinidad relacionada con las aguas, convendría tener en cuenta la relación del mito de Gerión con un río sagrado, el río Guadalquivir: dicen los textos clásicos que nació este personaje "casi enfrente de la ilustre Erytheia, junto a las fuentes inmensas de Tartesos, de raíces argénteas, en un escondrijo de la peña" (Estrabón, II,2,11). Del mismo modo, como ha sugerido algún especialista (Gracia 2003: 199), resulta tentador relacionar los apéndices de los cascos tartésicos con la leyenda de los bueyes de aquel personaje mítico. La combinación de estelas, agua y toros, ¿representa el modo indígena de entender la sacralización del territorio (pastos, agua, tierras, ... ), y del ganado vacuno, pilar básico de su economía y sociedad?; ¿esconden creencias religiosas autóctonas que pudieron quedar camufladas en el lenguaje del mito griego de Heracles y Gerión? (la complejidad simbólica de estas asociaciones es enorme. La relación entre el toro y las aguas en el mundo ibérico ya fue destacada en el año 1981 por E. Llobregat; sobre los altares de barro y otras construcciones y piezas del tipo denominado "en forma de lingote" y su simbolismo religioso como pieles de toros en época tartesia (Escacena 2000: 177 ss.) y Maier (2003); para la sacralización de las aguas en la protohistoria peninsular véase Blázquez y García Gelabert (1997); sobre el culto al toro es recomendable el artículo de estos mismos autores, 1997 y, fundamentalmente los de Maier (2004) y Chapa (2005); sobre la ligazón entre las aguas y el ámbito telúrico en la cultura ibérica, Olmos (1992 y 1996); y el valor sagrado e iniciático de las aguas en el mundo ibérico también ha sido estudiado por uno de nosotros, Fernández Rodríguez (1996: 310-311, con paralelos en otras culturas).

Con este trabajo sólo hemos pretendido hacer unas pocas reflexiones sobre la posible simbología de las estelas decoradas, a sabiendas de que sólo un conocimiento holístico de la cultura tartésica, permitirá en el futuro contar con los fundamentos necesarios para que estas y otras sugerencias alcancen siquiera la categoría de hipótesis con datos mejor contrastados de lo conocido hasta el momento.

\section{BIBLIOGRAFÍA}

ALMAGRO, M. (1966): Las estelas decoradas del suroeste peninsular. Biblioteca Praehistorica Hispana, VIII, Madrid.

- (1972): "Los ídolos y la estela decorada de Hernán Pérez (Cáceres) y el ídolo de Tabuyo del Monte (León)", Trabajos de Prehistoria 29: 83-112.

- (1974): "Nuevas estelas decoradas de la Península Ibérica”, Miscelánea Arqueológica XXV, Ampurias I: 5-39. Barcelona.

ALMAGRO GORBEA, M. (2004): "NIETHOS-Néit: The earliest documented Celtic God (c.575 BC) and the Atlantic relationships between Iberia and Ireland”, en H. Roche, E. Grogan, J. Bardley, J. Coles and B. Raftery (eds.), From Megaliths to Metal. Essays in Honour of George Eogan: 200-208. Oxbow Books.

ALVAR, J. (1999): "Manifestaciones religiosas", en J.M'. Blázquez, J. Alvar, C.G. Wagner, Fenicios y cartagineses en el Mediterráneo: cap. XXIX, 388-403. Cátedra, Madrid.

BELÉN, Ma . y ESCACENA, J. L. (1995): “Acerca del horizonte de la ría de Huelva. Consideraciones sobre el final de la Edad de Bronce en el Suroeste Ibérico", en Ritos de paso y puntos de paso. La ría de Huelva en el mundo del Bronce Final europeo. Servicio de publicaciones. Universidad complutense de Madrid.

BENDALA, M. (1977): "Notas sobre las estelas decoradas del suroeste y los orígenes de Tartessos", $\mathrm{Ha}$ bis 8: 117-205.

- (2000): Tartesios, iberos y celtas. Pueblos, culturas y colonizadores de la Hispania antigua. Temas de Hoy, Madrid.

BLÁZQUEZ, J. Ma . (2001): "Últimas aportaciones a las religiones prerromanas de España", en Religiones, ritos y creencias funerarias de la Hispania Prerromana: 143-160. Biblioteca Nueva, Madrid.

BLÁZQUEZ, J. M ${ }^{\mathrm{a}}$. y GARCÍA GELABERT, Mª.P. (1997): "Carácter sacro y funerario del toro en el mundo ibérico". Quaderns de Prehistoria i Arqueología de Castelló 18. Espacios y lugares cultuales en el mundo ibérico: 417-422.

- (1997): "El culto a las aguas en la Hispania prerromana”, Termalismo Antiguo. I Congreso Peninsular: 105-115. Madrid.

BRUIT, L. y SCMITT, P. (2002): La religión griega en la polis de la época clásica. Akal, Madrid.

CELESTINO, S. (2001): Estelas de guerrero y estelas diademadas. La precolonización y formación del mundo tartésico. Bellaterra Arqueología, Barcelona. 
CELESTINO, S. y LÓPEZ, C. (2004): “El motivo del toro guerrero en las estelas sirio-palestinas y sus analogías con las estelas tartésicas", Actas del VII Congreso Internacional de estelas funerarias, T. I.: 93-108. Fundación Marcelino Botín, Santander.

- (2006): "New Light on the warrior stelae fron Tartessos (Spain)", Antiquity 80: 89-101.

CURADO, F.P. (1984): "Uma nova estela do Bronze Final na Beira Alta (Baraçal, Sabugal. Guarda)", Arqueología 9: 81-84.

— (1986): "Uma nova estela do Bronze Final na Beira Alta (Foios, Sabugal. Guarda)", Arqueología 14: 103-109.

CHAPA, T. (2005): "Las primeras manifestaciones escultóricas ibéricas en el oriente peninsular", Archivo Español de Arqueología 78: 23-47.

DETIENNE, M. (2001): Apolo con el cuchillo en la mano. Una aproximación experimental al politeísmo griego. Akal, Madrid.

Díez de Velasco, F. (1995): Hombres, ritos, Dioses. Introducción a la Historia de las Religiones. Trotta, Madrid.

- (1998): Termalismo y Religión. La sacralización del agua termal en la Península ibérica y el norte de África en el mundo antiguo. Ilu. Revista de Ciencias de las Religiones, Madrid (también en www. ull.es/proyectos/aguarel/htm).

DOMÍNGUEZ, A. (2001): "La Religión en el emporion", Gerión 19: 221-257.

ESCACENA, J.L. (2000): La arqueología protohistórica del Sur de la Península Ibérica. Síntesis, Madrid.

FERNÁNDEZ CASTRO, M.C. (1997): La Prehistoria de la Península Ibérica. Historia de España, I. Crítica, Barcelona.

FERNÁNDEZ RODRÍGUEZ, J. (1996): “Mitos y ritos de paso en la concepción ibérica del poder: los relieves de Pozo Moro (Albacete)", Tabona IX: 297-316.

- (2005): "Espacios y caminos subterráneos en el imaginario ibérico de la muerte", en D. Sola (coord.), Imágenes de la muerte. Estudios sobre arte, arqueología y religión: 208-228. Documentos Congresuales, Universidad de La Laguna.

GABALDÓN MARTÍNEZ, Ma del Mar. (2004): Ritos de armas en la edad del Hierro. Armamento y lugares de culto en el antiguo mediterráneo y el mundo celta. Anejos de Gladius. C.S.I.C. Ediciones Polifemo. Madrid.

GALÁN, E. (1993): Estelas, paisajes y territorio en el Bronce Final del suroeste de la Península Ibérica. Complutum Extra 3, Madrid.

GARCÍA QUINTELA, M.V. (2001): Mitos hispánicos. La Edad Antigua. Akal, Madrid.
GARRIDO, J. P. (1998): “La aportación orientalizante en la necrópolis y hábitat de Huelva", en J.L. Cunchillos, J.M. Galán, J.Á. Zamora, S. Villanueva de Azcona (eds.), Actas del Congreso El Mediterráneo en la Antigüedad: Oriente y Occidente. Sapanu, Publicaciones en Internet II (http://www.labherm.filol.csic.es).

GARRIDO, J. P. y ORTA, E. M. (1994): El hábitat antiguo de Huelva (período orientalizante y arcaico). La primera excavación arqueológica en la calle del Puerto. Madrid.

GRACIA, F. (2003): La guerra en la Protohistoria. Héroes, nobles, mercenarios y campesinos. Ariel Prehistoria, Barcelona.

HARDING, A. F. (2003): Sociedades europeas en la Edad del Bronce. Ariel Prehistoria, Barcelona.

KRISTIANSEN, K y LARSSON, T.B. (2006): La emergencia de la sociedad del Bronce. Viajes, transmisiones y transformaciones. Ediciones Bellaterra, Barcelona.

LINCOLN, B. (1991): Sacerdotes, guerreros y ganado. Un estudio sobre la ecología de las religiones. Akal universitaria, $\mathrm{n}^{\mathrm{o}}$ 127. Madrid.

LONIS, R. (1979): Guerre et Religión en Grèce á l'Époque Classique. Paris.

LLOBREGAT, E. A. (1981): "Toros y agua en los cultos funerarios ibéricos", Saguntum 16: 149-164.

LÓPEZ PARDO, F. (2006): La torre de las almas. Un recorrido por los mitos y creencias del mundo fenicio y orientalizante a través del monumento de Pozo Moro. Gerión Anejos. Serie de Monografías. Anexo X. Publicaciones Universidad Complutense de Madrid.

MAIER, J. (2003): "El lingote en rama chipriota o de piel de toro: símbolo divino de la antigua iberia", A. García Barquero y P. Romero Solís (eds.), Fiestas de toros y sociedad: 85-106. Sevilla.

- (2004): "Imagen del toro en Tartessos", Revista de Estudios Taurinos 18: 51-80. Sevilla.

MARCO, F. (1993): "Heroización y tránsito acuático: sobre las diademas de Mones (Piloñas, Asturias)", en J. Mangas y J. Alvar. (eds.), Homenaje a José Ma . Blázquez. Vol. II: 319-348. Ediciones Clásicas, Madrid.

MOLINOS, M. et alii (1998): El santuario heroico de “El Pajarillo”. Huelma (Jaén). Universidad de Jaén.

MORENO ARRASTIO, F.J. (1998): "Sobre la objetividad, las estelas decoradas y sus agrupaciones", $\mathrm{Ge}$ rión 16: 49-84.

- (1999): “Conflictos y perspectivas en el período precolonial tartésico", Gerión 17.

OLMOS, R. (1987): "Nuevos enfoques para el estudio de la cerámica y de los bronces griegos de España: una primera aproximación al problema de la helenización", Cerámiques gregues i helenístiques a la Península Ibérica, Monografies Emporitanes VII: 7-17. 
- (1988): "El casco griego de Huelva", Clásicos de Huelva 1: 39-79. Excma. Diputación Provincial de Huelva.

- (1996): "Pozo Moro: ensayos de lectura de un programa escultórico en el temprano mundo ibérico", en R. Olmos (ed.), Al otro lado del espejo. Aproximación a la imagen ibérica: 85-98. Colección Lynx, Madrid.

OSUNA, M; BEDIA, J. y DOMÍNGUEZ, A. (2001): "El santuario protohistórico hallado en la calle Méndez Núñez (Huelva)", Cerámiques Jónies d'época arcaica: centres de producció, comercialització al Mediterrani Occidental. Monografies Emporitanes 11: 177-188.

RUIZ-GÁLVEZ, M. (1995): “Depósitos del Bronce Final: ¿sagrado o profano?, ¿sagrado y, a la vez, profano?”, en M. Ruiz-Gálvez (ed.), Ritos de paso y puntos de paso. La Ría de Huelva en el mundo del Bronce Final europeo. Complutum Extra 5: 21-32. Madrid.

- (1998): La Europa Atlántica en la Edad del Bronce. Un viaje a las raices de la Europa occidental. Crítica, Barcelona.

RUIZ-GÁLVEZ, M. y GALÁN, E. (1991): "Las estelas del suroeste como hitos de vías ganaderas y rutas comerciales", Trabajos de Prehistoria 48: 257-273.

TEJERA, A.; JORGE, S. y QUINTANA, R. (1995): "La estela IV de la Atalaya de Moranilla (Écija, Sevilla)", Spal 4: 251-255. http://dx.doi.org/10.12795/ spal.1995.i4.10

TORRES, M. (1999): Sociedad y mundo funerario en Tartessos. Biblioteca Archaeologica Hispana, 3, Real Academia de la Historia, Madrid. 


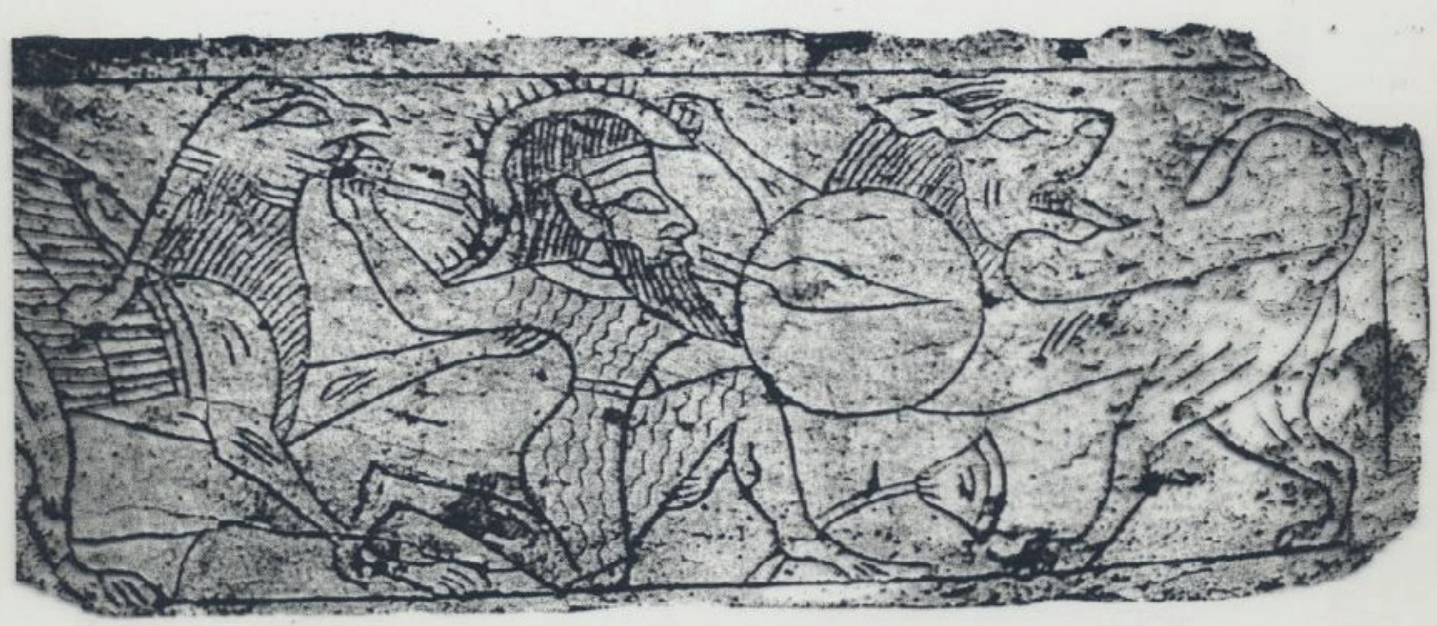

Fig. 1. Marfil de Bencarrón (Carmona, Sevilla). Representación de la figura de un león, grifo y un guerrero.

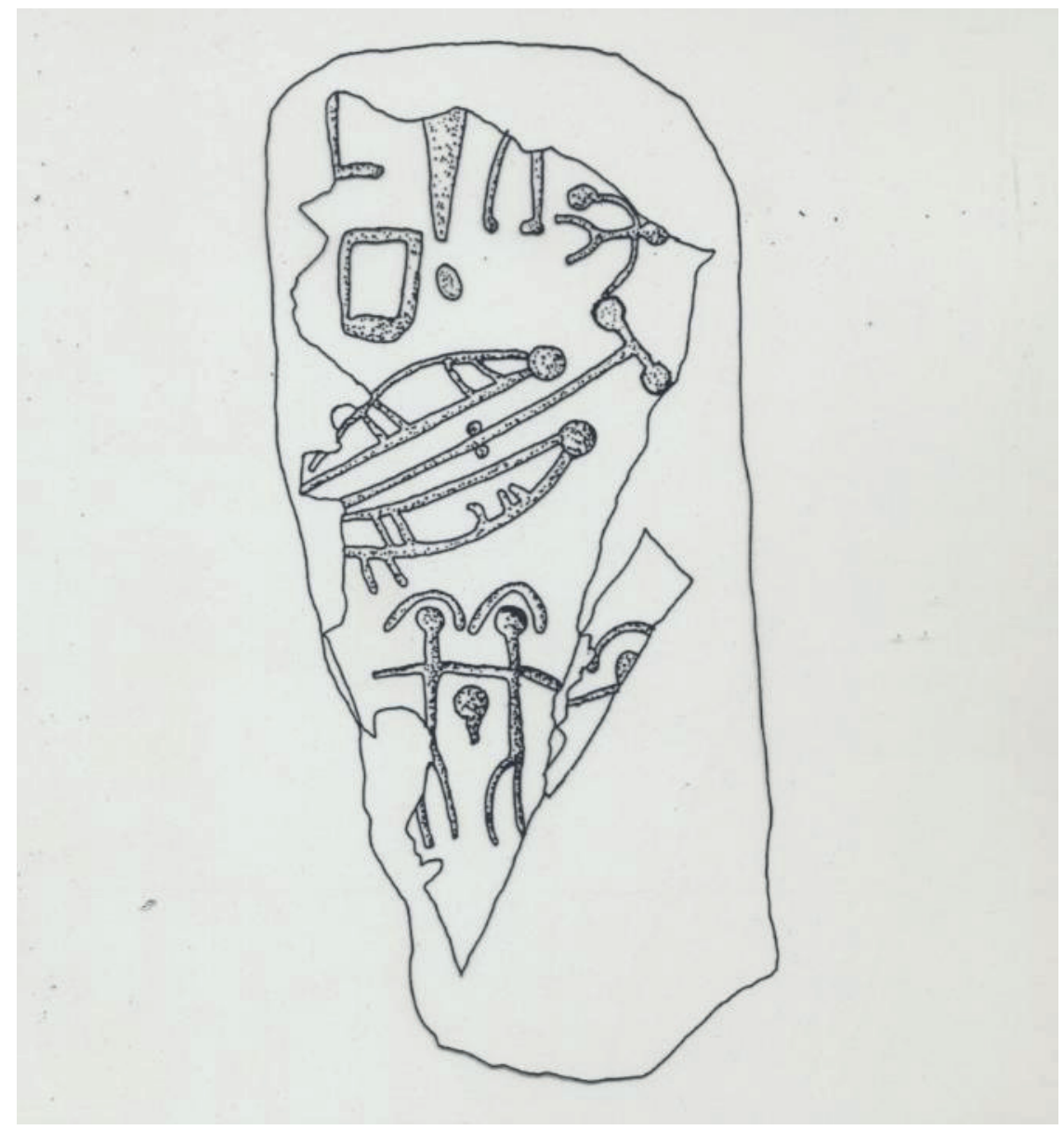

Fig. 2. Estela "Los Palacios". Procedente de Torres Alocaz (Sevilla). Representación de una pareja, que puede compararse a las figuras de gemelos de la tradición mítica de los indoeuropeos. 


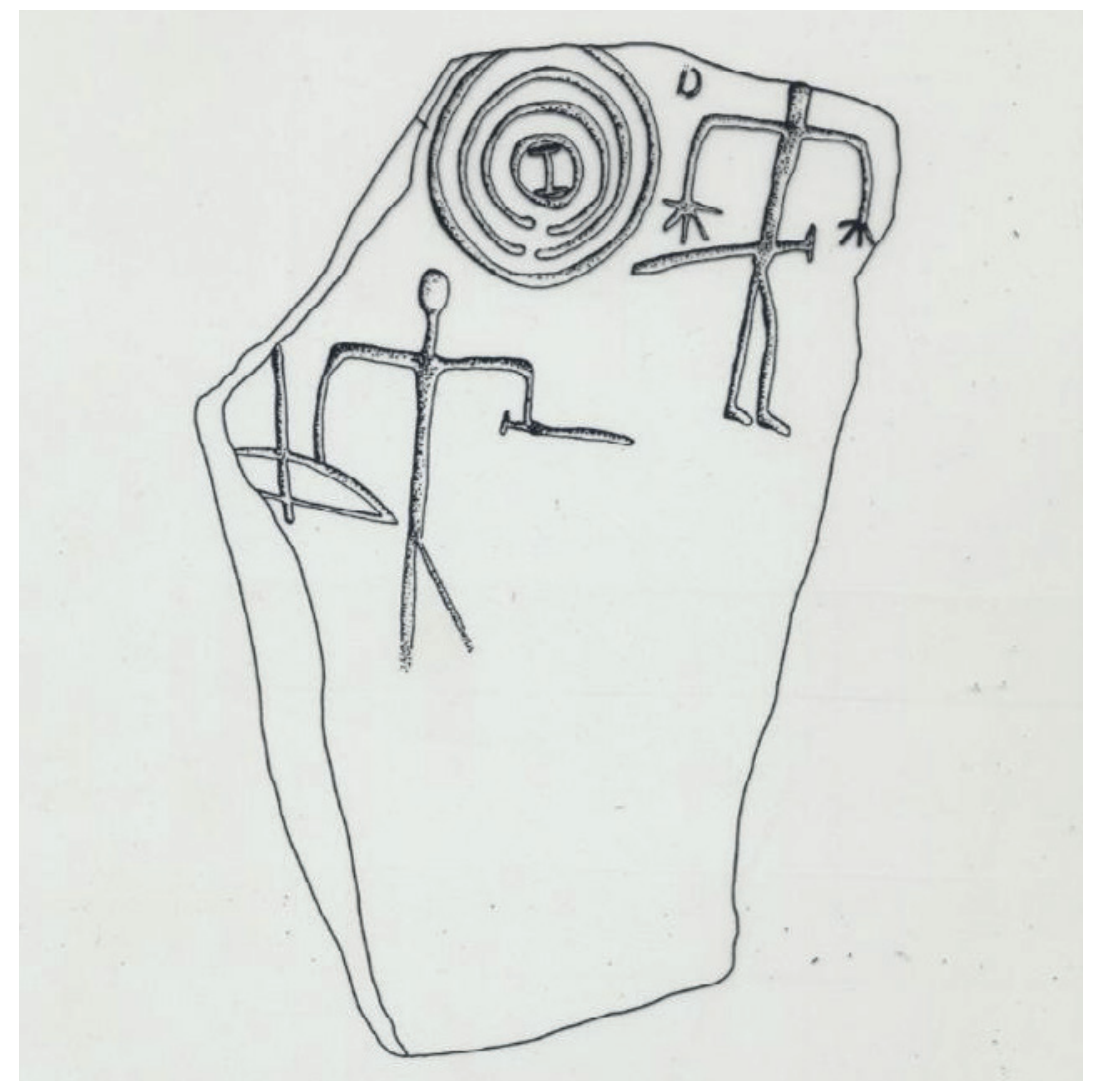

Fig. 3. Estela de "Zarza Capilla III". Representación de una pareja de figuras.

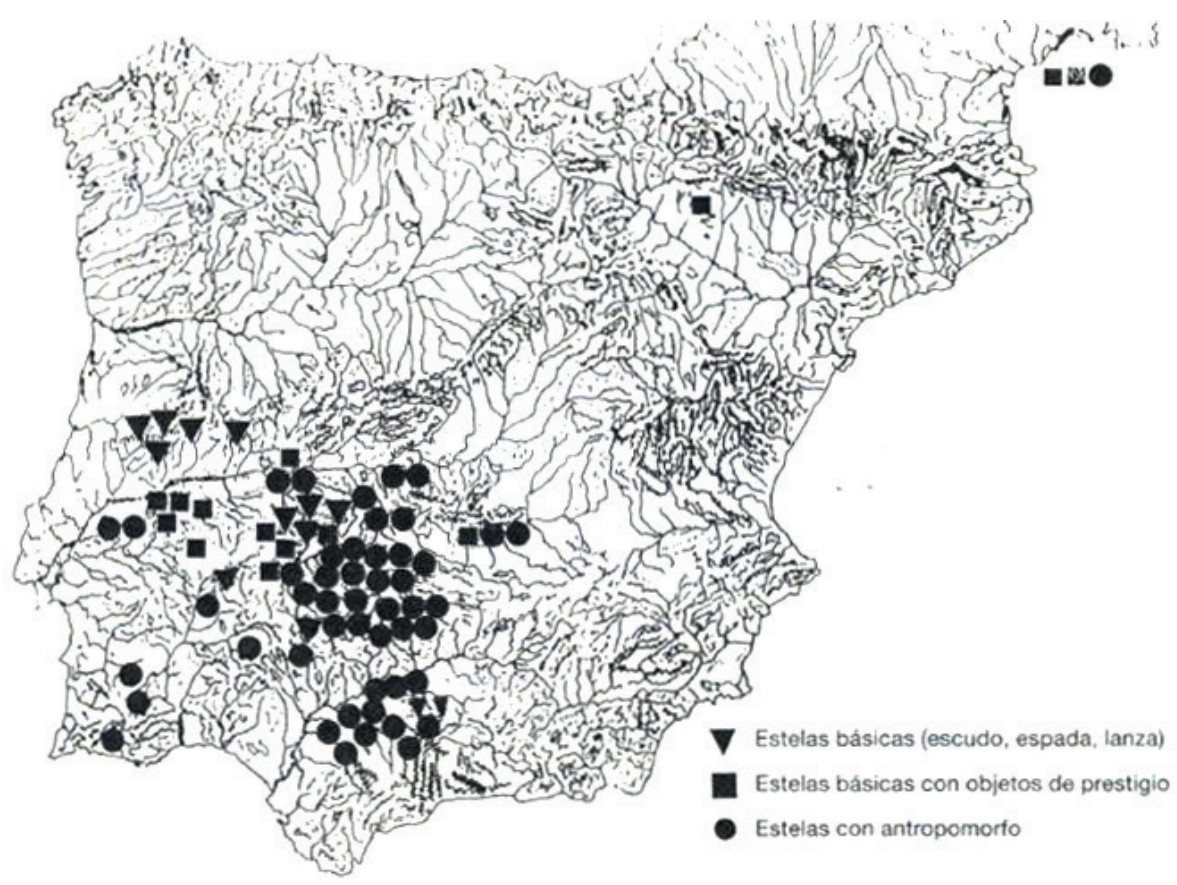

Fig. 4. Mapa de distribución de hallazgos de estelas (según Celestino 2001). 